\title{
DESCRIPTIONS OF THREE NEW SPECIES OF EUROPEAN HEMIPTERA-HOMOPTERA.
}

BY JOHN SCOTT.

Amongst the few species which I had put on one side as doubtful or undescribed species, collected by the Rev. T. A. Marshall in his travels abroad, I have now the pleasure to describe the three following, which I believe to be entirely new to science. My reason for this belief is that they were returned to me from the Continent, whither I had sent them for comparison with the collections and drawings of the late Dr. Fieber, as entirely unknown.

\section{Grathodus roseus.}

Reddish-pink. Elytra: anterior margin and nerves very pale straw-yellow ; 1st apical cell next the anterior margin deep fuscous.

Head-crown testaceous-yellow, slightly reddish in the middle. Face reddish-pink, with a narrow, longitudinal, yellowish line down each side of the centre, united towards the lower margin; frons broadly pale yellow. Antennce pale yellow; seta brown.

Thorax-pronotum pale testaceous-yellow ; disc more or less reddish-pink; near the anterior margin two small punctures placed one on each side of the centre. Scutellum pale testaceous-yellow, with a slight reddish-pink tinge next the base ; basal angles with a dark triangular patch and two small punctures between them above the transverse channel. Elytra reddish-pink; anterior margin, as far as the 1st nerve, very pale straw-yellow; nerves fine, pale straw-yellow, exterior margin of the 1st nerve next, and at, the apex narrowly margined with dark fuscous; apical cells pale; 1st, next the anterior margin, dark fuscous; appendix dark fuscous. Wings somewhat fuscous, apex of the anterior margin darker; nerves blackish. Legs dusky reddish-pink. Tibia: 3rd pair fuscous or brownish-red, base pale; spines brown, paler next the base, each set in a black puncture. Tarsi : 3rd pair pale fuscous.

Abdomen : above dark pink, sides broadly, and a narrow dorsal line, pale yellow.

Length, $1 \frac{1}{2}$ line.

The only other European species known to me is the G.punctatus, Thunb., with which the above cannot be confounded, as that insect is pale green and spotted with black.

Two or three examples from Corsica.

\section{Thamnotettix RUBRIVENosa.}

Whitish or yellowish-white with a reddish-tinge. Elytra spotted with brown, somewhat similar to Deltocephalus sabulicola; nerves, especially in the $q$, bright red. 
Head carmine-red. Crown with a narrow yellow central line not reaching to the base, near to which latter is a shallow fovea on each side having a minute black spot in the middle; on either side of the anterior margin is a short, somewhat comma-shaped, yellow streak, or frequently only a spot; frons carmine-red with a more or less decided yellow, cruciform character in the middle. Face more or less dark brown, with a yellow, longitudinal, central line joined to that on the frons, and gradually widening until it reaches the apex ; on each side about six transverse, narrow, yellow lines, the two upper ones generally joined exteriorly. Clypers yellow. Cheeks yellow. Antenna: 1st joint yellow, 2nd brownish, apex narrowly yellow; seta brown.

Thorax-pronotum broad, with a reddish tinge, anterior margin and a narrow longitudinal line, yellow; on each side of the latter in front a short black streak, and behind each eye a small black spot. Scutellum yellow, basal angles more or less red; transverse channel and a short line at each extremity forming a $\neg$-shaped character, blackish. Elytra whitish or yellowish-white with a reddish tinge. Clavus : nerves red; apex of the area enclosed by the axillary and anal nerves, and a streak in the middle, brown; apex and an oblong spot nearly in the centre of the area brown. Corium : nerves red; ante-apical area next the claval suture brown; apex of the exterior nerve of the adjoining ante-apical area on each side more or less broadly margined with brown, upper transverse nerve and an oblong spot above the middle of the area, brown; nerves of the apical areas dark brown, areas more or less fuscous. Sternum black, exterior margin of the segments broadly, posterior margin narrowly, yellow. Legs pale yellow. Thighs: all the pairs with a very short black streak, or one or two minute spots on the inside at the apex. Tibice: all the pairs narrowly brown down the interior margin, or sometimes the 1st and 2nd only spotted; 3rd pair: spines pale brown set in dark brown punctures.

Abdomen: above black; posterior margin of the segments narrowly yellow; side margins narrowly rosy.

q. All the characters as in the other sex, except that the nerves of the elytra are of a brighter red, and give to the insect a much more rosy appearance.

Habitat: Corsica.

Length, $1 \frac{1}{2}$ line.

\section{Phlepsius filigranus.}

White. Elytra: nerves very pale brownish-yellow, minutely and irregularly spotted with dark brown; disc with very fine transverse reticulations.

Head-crown yellowish-white with a somewhat indistinct pale central line, and a small black spot in front on each side of the apex. Face very faintly brownish with a narrow, longitudinal, central line, and several transverse ones, yellowish. Eyes somewhat reddish. Antennce pale yellowish; setce, towards the apex, brown.

Thorax - pronotum very faintly brownish, round the anterior margin pale yellowish ; disc irrorated with white, and with a central longitudinal line of the same colour. Scutellum yellowish-white, with a darker triangular patch at each basal angle. 
Elytra white. Clavus : nerves very pale brownish-yellow, disc between the latter sparingly but finely reticulated transversely with dark brown, sometimes occurring as minute spots; apex dark brown. Corium: nerves very pale brownishyellow, minutely but irregularly spotted with dark brown; disc finely reticulated transversely with dark brown, areas here and there with a few minute dark brown spots in irregular clusters. Sternum pale yellowish. Mesosternum posteriorly spotted with very pale brown. Legs pale yellowish. Tibice : 3rd pair; spines pale, each set in a dark brown puncture. Tarsi: 3rd pair faintly brownish. Claws brown.

Abdomen: underneath pale yellow ; posterior margin of the segments next the connexivum finely reddish-brown.

Length, 2 lines.

A single ơ example labelled Nimes.

Lee: July $11 t h, 1876$.

BRITISH HEMIPTERA-HETEROPTERA-ADDITIONAL SPECIES.

By O. M. Reuter (Helsingfors).

\section{PLESIODEMA, Reut.*}

Body sub-elongate, finely pale pubescent, not covered with a short, deciduous, scale-like pubescence. Head, across the eyes, about half as wide as the width of the basal margin of the pronotum, inclined, shining. Neck without a carina. Clypeus slender, very little prominent, its base in the intermedian line of the eyes. Eyes granulated, touching the anterior margin of the pronotum. Antennæ inserted near the apex of the inner ocular margin ; 1st joint not exceeding the apex of the clypeus, 2 nd joint as long as 3rd and 4th. Rostrum a little exceeding the posterior coxæ; 1st joint reaching to the middle of the xyphus, $3 \mathrm{rd}$ and 4 th joints thin. The throat very short. Pronotum, between the basal angles, twice as wide as long, disc very slightly convex, shining, the calli distinct, the side margins and the basal margin nearly straight. Scutellum with the base not covered. Hemelytra developed, membrane with two cells. Wing-cells with a hook-like nerve. Xyphus of the prosternum very convex. Thighs not incrassated, not spotted. Tibiæ with thin, concolorous spines. 3rd joint of the tarsi as long as 1st and 2nd together. Terebra of the $q$ long.

\section{P. Pinetellum, Zett.}

Capsus pinetellus, Zett., Ins. Lap.; Kirschb., Rh. Wiesb.; Flor, Rh. Livl. Agalliastes lugubris, Fieb., Eur. Hem. Plagiognathus pallidipennis, J. Sahlb., Not. F. et Fl. Fenn. Plesiodema pinetellum, Reut., Rev. Crit. Caps.

$\delta$ and $q$ discolorous. 


\section{$2 \mathrm{BHL}$ Biodiversity Heritage Library}

Scott, J. 1876. "Descriptions of three new species of European

Hemiptera-Homoptera." The Entomologist's monthly magazine 13, 83-85.

https://doi.org/10.5962/bhl.part.22818.

View This Item Online: https://www.biodiversitylibrary.org/item/35879

DOI: https://doi.org/10.5962/bhl.part.22818

Permalink: https://www.biodiversitylibrary.org/partpdf/22818

\section{Holding Institution}

Smithsonian Libraries

\section{Sponsored by}

Smithsonian

\section{Copyright \& Reuse}

Copyright Status: NOT_IN_COPYRIGHT

This document was created from content at the Biodiversity Heritage Library, the world's largest open access digital library for biodiversity literature and archives. Visit BHL at https://www.biodiversitylibrary.org. 